\title{
Recent Trends of Demersal Marine Fish and Invertebrate Production in Southeast Asia - A Hypothesis-based Analysis
}

\author{
Vinay P. Padate ${ }^{1}$ and Chandrashekher U. Rivonker ${ }^{1, *}$ \\ ${ }^{1}$ Department of Marine Sciences, Goa University, Taleigao Plateau, Goa, India 403206 \\ *Corresponding author: curivonker@gmail.com
}

\author{
KEYWORDS \\ Algal blooms \\ Demersal fish landings \\ Land use pattern \\ Resource expansion \\ Southeast Asia \\ Trophic dynamics
}

\begin{abstract}
Demersal marine fish and invertebrate production data for Southeast Asia (1996-2007) obtained from the Southeast Asian Fisheries Development Center (SEAFDEC) statistical bulletin indicated a reduced production by Thailand largely due to over-exploitation and altered coastal ecosystems. In contrast, increased production by Philippines, Indonesia and Malaysia was due to an increase in mechanised fishing fleets. Moreover, marginal increases in the ecosystem indicators were attributed to increased exploitation of high and mid trophic level organisms suggesting the development of "top-down" cascade effect in the future. In this bioregion, land use pattern affecting water quality coupled with altered monsoonal sequences and rising sea surface temperatures interfere with biological processes. The most apparent manifestations of these disturbances are recurrences of extensive algal blooms and coral bleaching events. Fish mortality as a result of these events threatens to weaken the native biota and facilitate invasions that would modify the trophic dynamics of the coastal habitats.
\end{abstract}

(c) The Author(s) 2018. This article is distributed under a Creative Commons Attribution-ShareAlike 4.0 International license.

\section{INTRODUCTION}

The biologically diverse coastal seas in Southeast Asia (Figure 1), endowed with myriad faunal assemblages (Kathiresan and Rajendran 2005; Keesing and Irvine 2005; Mazlan et al. 2005), are aptly regarded as the epicentre of global marine biodiversity. The coastal wetlands in this region harbour 75 species of mangrove trees (Son and Thuoc 2003), and some 700 scleractinian coral species in reefal habitats (Hutomo and Moosa 2005; Keesing and Irvine 2005). These ecosystems, besides being natural barriers to tropical storms and tsunamis, support approximately $40 \%$ of the marine fish species found in the region with high levels of endemicity (Keesing and Irvine 2005). However, the utility of mangroves and corals as construction material, conversion of wetlands into aquaculture farms, coastal pollution (Hutomo and Moosa 2005), land reclamation for human settlements, and destructive fishing activities (Burke et al. 2002) are potentially perilous to these fragile ecosystems.

On the other hand, recent shifts in monsoonal sequences and increasing sea surface temperature associated with the El Niño and La Niña phenomena have wreaked havoc through frequent tropical cyclones, coral bleaching events (Mazlan et al. 2005) and harmful algal bloom formations (Wang et al. 2008), thereby potentially altering ecosystem functions like fisheries. Stocks of large demersal and small pelagic fish, as well as benthic invertebrates are threatened owing to demand-driven uninhibited fishing by mechanized fishing vessels and other destructive techniques in coastal and deeper waters (Armada 2004; Barut et al. 2004; Hutomo and Moosa 2005; Morgan and Staples 2006). The above events could potentially alter the life cycles and ecology of the resident faunal assemblages with long-lasting effects on the biological processes including feeding, migration and reproduction, with disastrous consequences for commercially exploitable fish and invertebrate stocks in the region.

In view of above, the present study seeks to provide a synoptic view of the demersal marine fisheries trends of the Southeast Asian region during 1996-2007. Further, we take a holistic approach to determine the causes of decline of marine fisheries in this region during the above period with due consideration on the roles of both natural and anthropogenic factors.

\section{MATERIALS AND METHODS}

\subsection{Abbreviations used}

CPUE - Catch per unit effort; FiB - Fishing-in-Balance Index; HAB - Harmful Algal Bloom; HTL - High Trophic Level organisms; LTL - Low Trophic Level organisms; MMT - Million metric tonnes; MTI - Marine Trophic Index; MTL - Mid Trophic Level organisms; SEAFDEC Southeast Asian Fisheries Development Center; SST - Sea Surface Temperature.

\subsection{Data collation}

Marine capture fishery and aquaculture production datasets of nine Southeast Asian countries (Brunei Darussalam, Cambodia, Indonesia, Malaysia, Myanmar, Philippines, Singapore, Thailand and Vietnam; Figure 2) for the period from 1996-2007 were obtained from the SEAFDEC (2013). Subsequently, available datasets of 53 demersal (and bentho-pelagic) fishery groups from only four out of the nine countries (Thailand, Indonesia, Malaysia and Philip- 
pines) were obtained from SEAFDEC (2013), clumped into three broad categories namely demersal fishes (37 groups/species), crustaceans (eight groups) and molluscs (eight groups), and their trends were examined. Additionally, certain bentho-pelagic fishes such as carangids and hairtails were also included in the analysis due to their occurrence in the demersal trawl hauls. Moreover, 18 pelagic fish groups (Appendix 1) were included to aid in hypothesizing ecological responses of both demersal and pelagic fish and invertebrate assemblages to climate change and anthropogenic interference.

In addition, datasets indicating the size of the marine fishing fleets and categories of vessels (available for only three countries namely Indonesia, Malaysia and Thailand) were obtained from SEAFDEC (2013). Altogether, available data for 10 types of vessels were classified into five categories namely Non-powered, Outboard powered, Small inboard powered (including $<5$ tons, 5-10 tons, 20 tons, 20-50 tons), Medium inboard powered (including 50-100 tons, 100-200 tons) and Large inboard powered (including 200-500 tons, 500 tons and over) vessels.

\subsection{Fish stock assessment}

Stock status of all 53 demersal fisheries of the above four countries (considering the year 1996 as the base/initial year) was examined separately following the criteria (Table 1) provided by Froese and Kesner-Reyes (2002).

\subsection{Ecosystem health assessment}

Ecosystem indicators such as MTI (Pauly et al. 1998) and FiB (Pauly et al. 2000) were computed using the catch data to assess the status of marine demersal capture fisheries of four countries and their effects on the coastal ecosystems. For these analyses, trophic levels of the demersal species examined were obtained from Fishbase (Froese and Pauly 2013) and Sea Around Us Project (Pauly 2013). Subsequently, demersal species/groups examined were segregated into three trophic levels namely HTL $(>3.51)$, MTL (2.51-3.50) and LTL $(<2.51)$ after modifications in trophic level criteria provided by Vivekanandan et al. (2005).

\subsection{Country-wise comparison of catch trends among trophic levels}

Catch figures of individual species obtained from published data (SEAFDEC 2013) within a particular trophic level group (HTL, MTL or LTL) were summed up and their trends were compared for the period from 1996-2007.

\subsection{Overview of catastrophic events}

Review of literature on HAB and coral bleaching events that occurred during 1996-2007 was undertaken to collate information on these catastrophic events, in order to assess their effects on the marine fisheries production trends throughout Southeast Asia.

\section{RESULTS}

3.1 Overall trends: marine capture fisheries and aquaculture

Marine fish (and invertebrate) production through marine capture fisheries and aquaculture sectors in Southeast Asia displayed an increasing trend from 1996-2007. However, during the above period, production through capture fisheries increased only $41.8 \%$, as compared to $285.3 \%$ through aquaculture (Figure 2A).

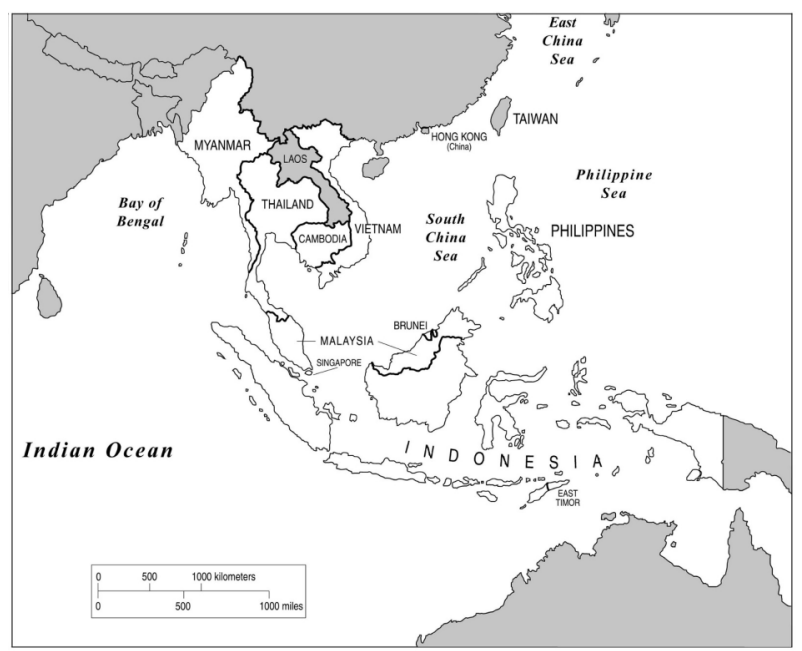

Figure 1. Map of Southeast Asia indicating the geographical extent of the study area.

\subsection{Marine capture fisheries: overall trends}

Six countries registered increase in marine fisheries (demersal and pelagic) landings as follows: Myanmar (119.8\%), Vietnam (106.5\%), Cambodia (76.0\%), Philippines (44.6\%), Indonesia (39.9\%) and Malaysia (22.6\%) (Figure 2B-G). On the other hand, marine fish landings decreased in three countries, namely Singapore (63.6\%), Brunei Darussalam (55.3\%) and Thailand (25.4\%) (Figure 2H-J).

\subsection{Marine demersal capture fisheries: country-wise trends}

Datasets from only four countries namely Indonesia, Malaysia, Philippines and Thailand were selected for the analysis due to availability of continuous data from 1996-2007. The numbers of fishery groups analyzed for the above countries were $41,41,45$, and 36 , respectively (Table 2). The combined trends of marine demersal species production in these countries revealed an $18.0 \%$ increase during the above period. Country-wise trends for the period from 1996-2007 are provided below.

\subsubsection{Indonesia}

Total demersal landings increased from 1.901 MMT in 1996 to 2.611 MMT in 2007 (37.3\% increase). Landings of demersal fishes, crustaceans and molluscs increased by $37.6 \%, 52.8 \%$ and $2.0 \%$, respectively, during the above period (Figure 3B). Out of the 41 fishery groups assessed, stocks of five groups were overfished, 29 fully exploited, whereas fisheries of seven groups were developing (Table 2).

\subsubsection{Malaysia}

Total demersal landings increased from 0.851 MMT in 1996 to 1.027 MMT in 2007 (21.68\% increase). Landings of demersal fishes and molluscs increased by $25.6 \%$ and

Table 1. Criteria for determining the status of exploitable fish stocks.

\begin{tabular}{|c|c|c|}
\hline $\begin{array}{l}\text { Sr. } \\
\text { No. }\end{array}$ & Status of fishery & Criterion applied \\
\hline 1. & Undeveloped & $\begin{array}{l}\text { Year before maximum production and } \\
\text { production less than } 10 \% \text { of maximum value. }\end{array}$ \\
\hline 2. & Developing & $\begin{array}{l}\text { Year before maximum production and } \\
\text { production } 10-50 \% \text { of maximum value. }\end{array}$ \\
\hline 3. & Fully exploited & Production larger than $50 \%$ of maximum value. \\
\hline 4. & Overfished & $\begin{array}{l}\text { Year after maximum production and } \\
\text { production } 10-50 \% \text { of maximum value. }\end{array}$ \\
\hline 5. & Collapsed & $\begin{array}{l}\text { Year after maximum production and } \\
\text { production less than } 10 \% \text { of maximum value. }\end{array}$ \\
\hline
\end{tabular}


(A)

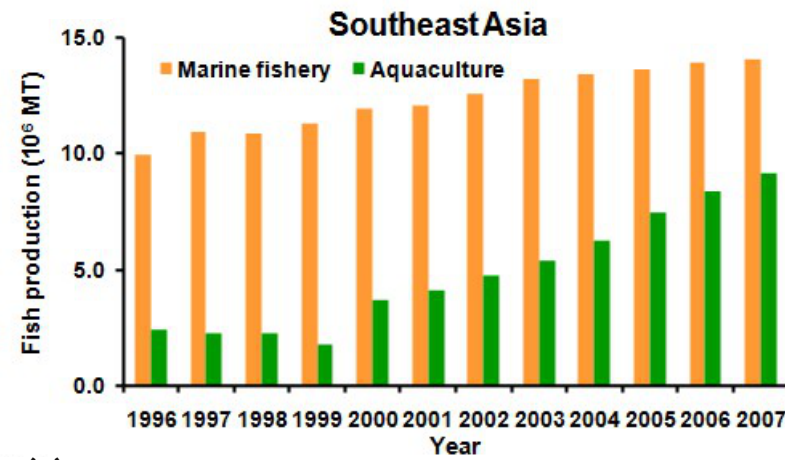

(c)

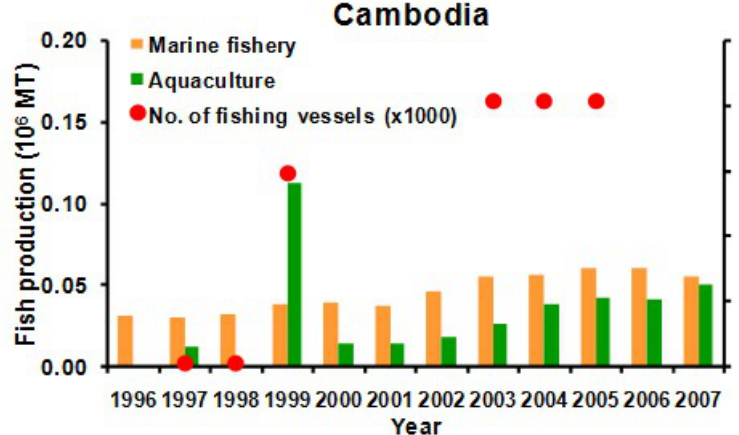

(E)

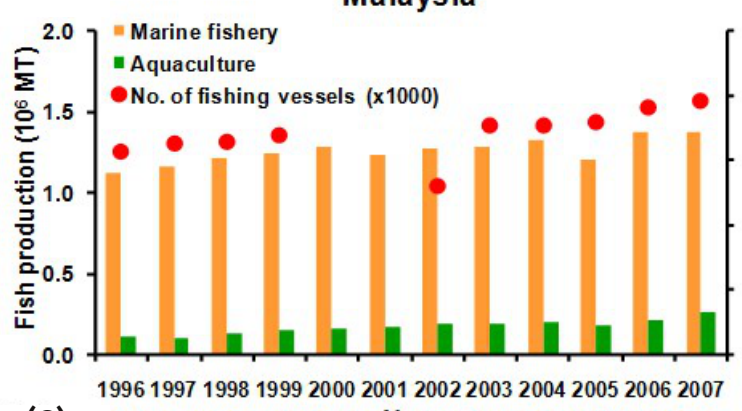

(G)

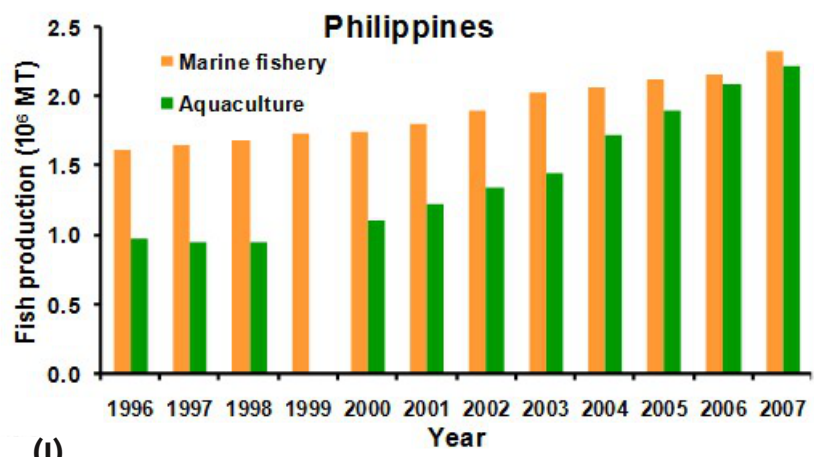

(I)

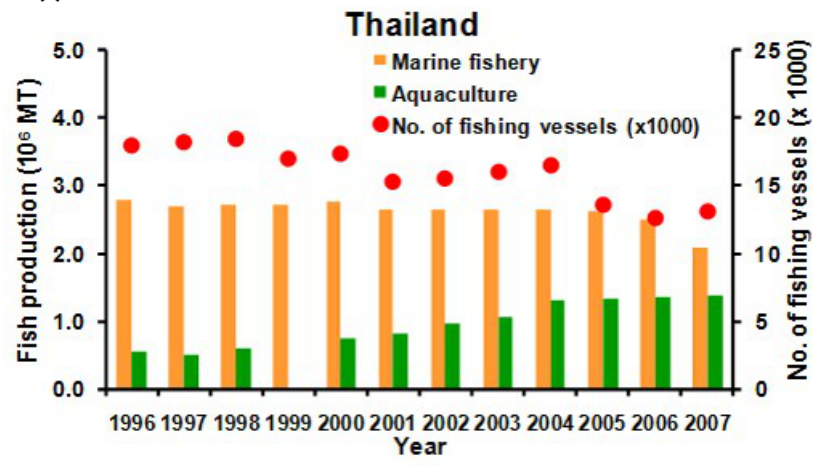

(B)

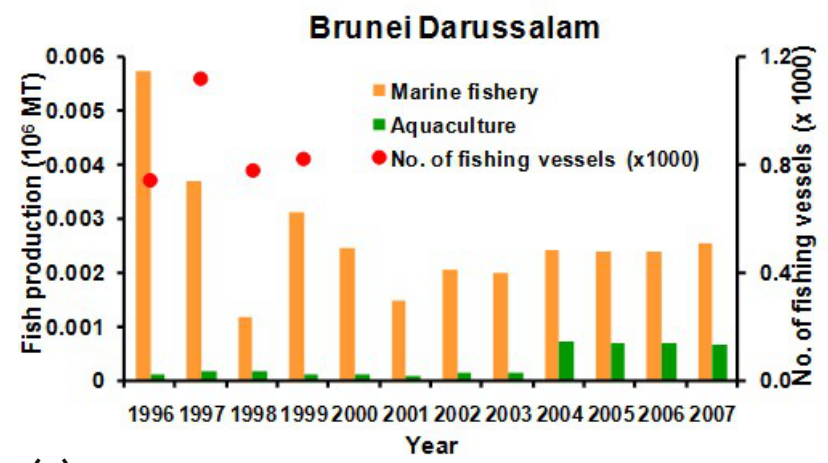

(D)

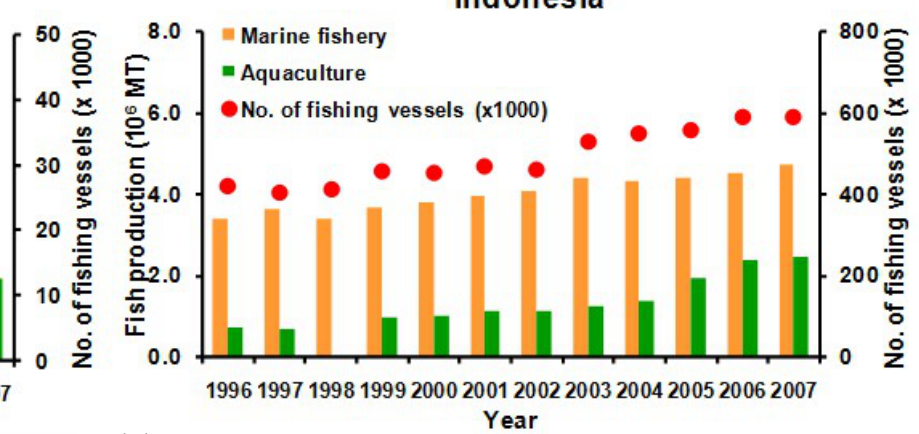

(F)

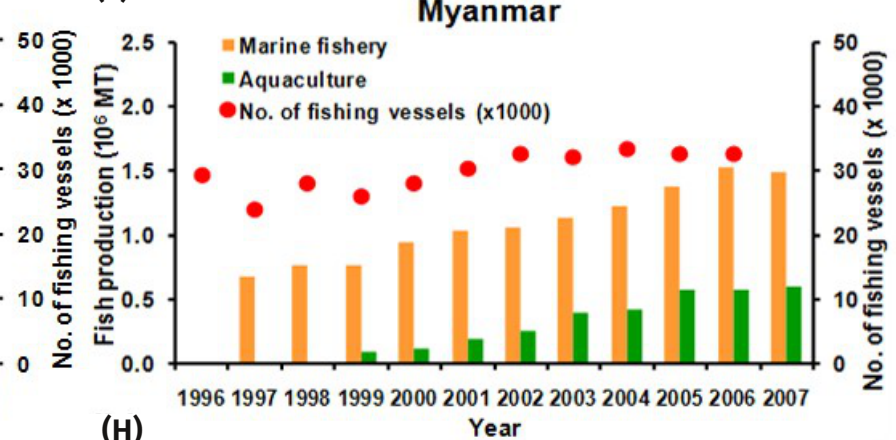

Singapore

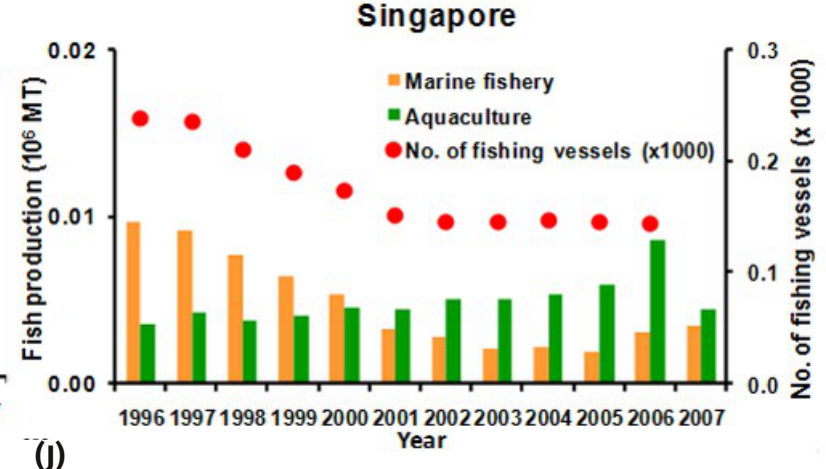

Vietnam

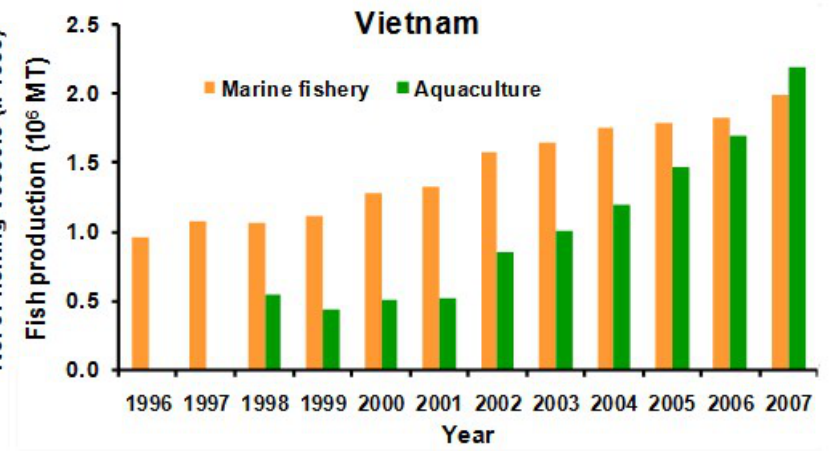

Figure 2. Production trends of marine capture fishery and aquaculture sectors during 1996-2007. (A) Southeast Asia; (B) Brunei Darussalam, (C) Cambodia, (D) Indonesia, (E) Malaysia, (F) Myanmar, (G) Philippines, (H) Singapore, (I) Thailand, and (J) Vietnam. 
Table 2. Exploitation status of marine demersal and benthopelagic fishery resources (finned fishes, crustaceans and molluscs) of four Southeast Asian countries during 1996-2007. Abbreviations: C - Collapsed; D - Developing; FE - Fully exploited; id - insufficient data (not included in analysis); OF Over-fished; UD - Under-developed (see Table 1 for definitions).

\begin{tabular}{|c|c|c|c|c|c|c|}
\hline \multirow{2}{*}{$\begin{array}{l}\text { Sr. } \\
\text { No. }\end{array}$} & \multirow[t]{2}{*}{ Fishery group } & \multirow{2}{*}{$\begin{array}{l}\text { Trophic } \\
\text { Level \& Group }\end{array}$} & \multicolumn{4}{|c|}{ Status of exploitation (Country) } \\
\hline & & & Indonesia & Malaysia & Philippines & Thailand \\
\hline
\end{tabular}

\begin{tabular}{|c|c|c|c|c|c|c|c|}
\hline A. & FINNED FISHES & & & & & & \\
\hline 1. & Barramundi & 4.35 & HTL & $\mathrm{D}$ & $\mathrm{FE}$ & OF & OF \\
\hline 2. & Big-eyesnappers & 3.81 & HTL & $\mathrm{D}$ & id & OF & $\mathrm{FE}$ \\
\hline 3. & Black pomfret & 3.64 & HTL & $\mathrm{FE}$ & OF & $\mathrm{FE}$ & $\mathrm{FE}$ \\
\hline 4. & Breams & 3.31 & MTL & id & $\mathrm{FE}$ & id & id \\
\hline 5. & Catfish eels & 3.09 & MTL & id & $\mathrm{FE}$ & id & OF \\
\hline 6. & Drums \&croakers & 3.76 & HTL & $\mathrm{FE}$ & $\mathrm{FE}$ & $\mathrm{FE}$ & $\mathrm{FE}$ \\
\hline 7. & Eels & 3.99 & HTL & id & $\mathrm{FE}$ & $\mathrm{FE}$ & $\mathrm{FE}$ \\
\hline 8. & Emperor breams & 3.59 & HTL & $\mathrm{FE}$ & id & $\mathrm{FE}$ & id \\
\hline 9. & Goat fishes & 3.46 & MTL & $\mathrm{FE}$ & $\mathrm{FE}$ & $\mathrm{FE}$ & id \\
\hline 10. & Groupers & 3.98 & HTL & $\mathrm{FE}$ & $\mathrm{FE}$ & $\mathrm{FE}$ & $\mathrm{FE}$ \\
\hline 11. & Grunters \&sweetlips & 3.36 & MTL & $\mathrm{FE}$ & $\mathrm{FE}$ & $\mathrm{FE}$ & id \\
\hline 12. & Hairtails & 4.45 & HTL & $\mathrm{FE}$ & $\mathrm{FE}$ & $\mathrm{FE}$ & $\mathrm{FE}$ \\
\hline 13. & Indian halibuts & 4.34 & HTL & $\mathrm{FE}$ & $\mathrm{FE}$ & id & OF \\
\hline 14. & Jacks, Cavalla, Trevallies & 4.05 & HTL & $\mathrm{FE}$ & $\mathrm{FE}$ & $\mathrm{FE}$ & $\mathrm{FE}$ \\
\hline 15. & Lizard fishes & 4.30 & HTL & $\mathrm{D}$ & $\mathrm{D}$ & $\mathrm{FE}$ & $\mathrm{FE}$ \\
\hline 16. & Marine catfishes & 3.48 & MTL & $\mathrm{FE}$ & $\mathrm{FE}$ & $\mathrm{FE}$ & OF \\
\hline 17. & Miscellaneous fishes & 3.50 & MTL & $\mathrm{FE}$ & $\mathrm{FE}$ & D & $\mathrm{FE}$ \\
\hline 18. & Mullets & 2.53 & MTL & $\mathrm{FE}$ & $\mathrm{FE}$ & $\mathrm{FE}$ & OF \\
\hline 19. & Other snappers & 4.02 & HTL & id & OF & id & id \\
\hline 20. & Other species (Jacks, etc.) & 4.05 & HTL & OF & $c$ & $\mathrm{FE}$ & id \\
\hline 21. & Other species (Redfishes, etc.) & 4.00 & HTL & id & $\mathrm{FE}$ & $\mathrm{FE}$ & OF \\
\hline 22. & Pony fishes & 3.24 & MTL & $\mathrm{FE}$ & $\mathrm{FE}$ & $\mathrm{FE}$ & id \\
\hline 23. & Queenfishes & 4.47 & HTL & $\mathrm{FE}$ & $\mathrm{FE}$ & $\mathrm{FE}$ & id \\
\hline 24. & Rabbitfishes & 2.11 & LTL & id & $\mathrm{FE}$ & $\mathrm{FE}$ & id \\
\hline 25. & Rays & 3.61 & HTL & $\mathrm{FE}$ & $\mathrm{FE}$ & $\mathrm{FE}$ & OF \\
\hline 26. & Red snappers & 4.02 & HTL & $\mathrm{FE}$ & $\mathrm{FE}$ & id & $\mathrm{FE}$ \\
\hline 27. & Round scads & 3.63 & HTL & $\mathrm{FE}$ & $\mathrm{FE}$ & $\mathrm{FE}$ & $\mathrm{FE}$ \\
\hline 28. & Selar scads & 3.89 & HTL & $\mathrm{FE}$ & $\mathrm{FE}$ & $\mathrm{FE}$ & $\mathrm{FE}$ \\
\hline 29. & Sharks & 4.25 & HTL & $\mathrm{FE}$ & $\mathrm{FE}$ & $\mathrm{FE}$ & OF \\
\hline 30. & Sillago whitings & 3.25 & MTL & id & $\mathrm{FE}$ & $\mathrm{FE}$ & $\mathrm{FE}$ \\
\hline 31. & Soles & 3.15 & MTL & id & id & $\mathrm{FE}$ & id \\
\hline 32. & Threadfins & 3.62 & HTL & $\mathrm{FE}$ & $\mathrm{FE}$ & $\mathrm{FE}$ & OF \\
\hline 33. & Threadfin breams & 3.51 & HTL & $\mathrm{D}$ & $\mathrm{FE}$ & $\mathrm{FE}$ & $\mathrm{FE}$ \\
\hline 34. & Tongue soles & 3.29 & MTL & id & $\mathrm{D}$ & id & OF \\
\hline 35. & Trash fish & 3.20 & MTL & id & $\mathrm{FE}$ & id & $\mathrm{FE}$ \\
\hline 36. & White pomfret & 3.41 & MTL & $\mathrm{D}$ & id & id & $\mathrm{D}$ \\
\hline 37. & Wolf herring & 4.50 & HTL & $\mathrm{FE}$ & $\mathrm{FE}$ & $\mathrm{FE}$ & $\mathrm{FE}$ \\
\hline B. & CRUSTACEANS & & & & & & \\
\hline 1. & Mangrove crab & 3.17 & MTL & D & id & OF & OF \\
\hline 2. & $\begin{array}{l}\text { Miscellaneous } \\
\text { marine crustaceans }\end{array}$ & 2.60 & MTL & OF & id & $\mathrm{FE}$ & id \\
\hline 3. & Other prawns & 2.70 & MTL & $\mathrm{FE}$ & $\mathrm{FE}$ & $\mathrm{FE}$ & OF \\
\hline 4. & Penaeid prawns & 2.70 & MTL & $\mathrm{FE}$ & $\mathrm{FE}$ & $\mathrm{FE}$ & OF \\
\hline 5. & Slipper lobster & 2.87 & MTL & id & id & OF & id \\
\hline 6. & Spiny lobsters & 2.60 & MTL & $\mathrm{FE}$ & OF & OF & id \\
\hline 7. & Swimming crabs & 3.56 & HTL & $\mathrm{FE}$ & $\mathrm{FE}$ & $\mathrm{FE}$ & $\mathrm{FE}$ \\
\hline 8. & Tiger prawn & 2.60 & MTL & $\mathrm{FE}$ & $\mathrm{FE}$ & $\mathrm{FE}$ & $\mathrm{FE}$ \\
\hline c. & MOLLUSCS & & & & & & \\
\hline 1. & Blood cockles & 2.00 & LTL & $\mathrm{FE}$ & id & OF & OF \\
\hline 2. & Clams \& coneshells & 2.00 & LTL & OF & id & OF & id \\
\hline 3. & Cupped oysters & 2.00 & LTL & OF & id & OF & id \\
\hline 4. & Cuttlefishes & 3.60 & HTL & OF & $\mathrm{FE}$ & $\mathrm{FE}$ & $\mathrm{FE}$ \\
\hline 5. & Octopuses & 3.58 & HTL & $\mathrm{FE}$ & $\mathrm{FE}$ & OF & OF \\
\hline 6. & Scallops & 2.00 & LTL & $\mathrm{D}$ & id & OF & OF \\
\hline 7. & Sea mussels & 2.00 & LTL & id & id & OF & id \\
\hline 8. & Squids & 4.13 & HTL & $\mathrm{FE}$ & $\mathrm{FE}$ & $\mathrm{FE}$ & $\mathrm{FE}$ \\
\hline
\end{tabular}


(A)

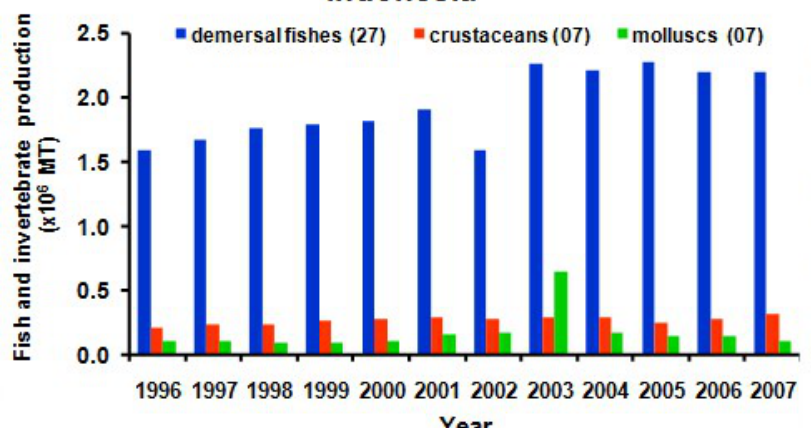

(C)

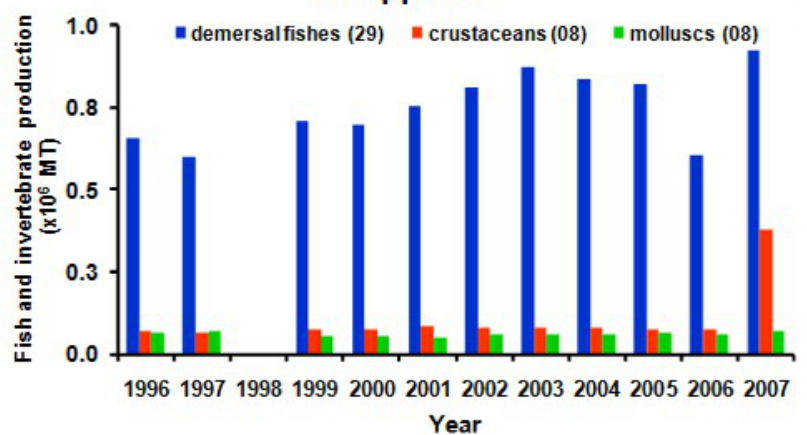

(B)

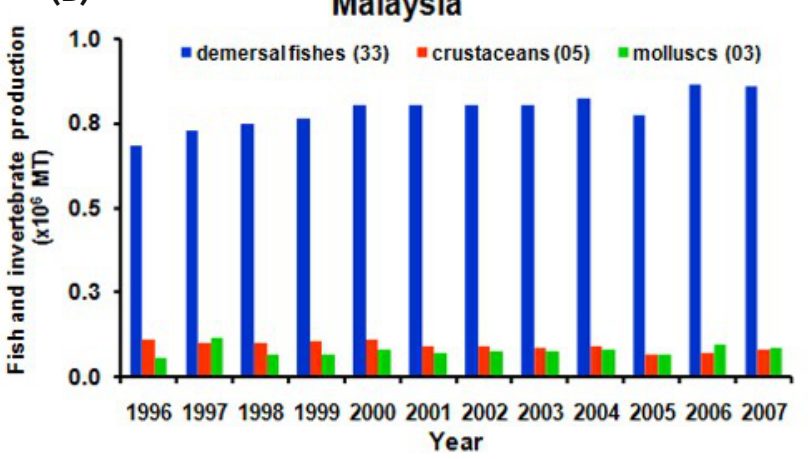

(D)

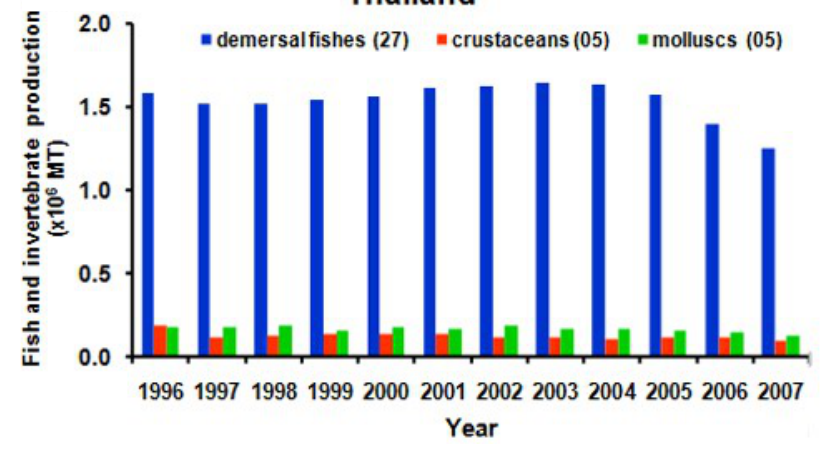

Figure 3. Landing trends of demersal fishes, crustaceans and molluscs during 1996-2007 in selected countries in Southeast Asia. (A) Indonesia, (B) Malaysia, (C) Philippines and (D) Thailand.

(A)

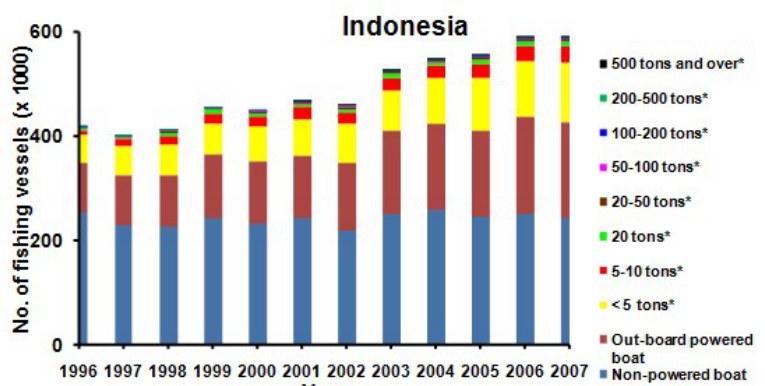

(B)

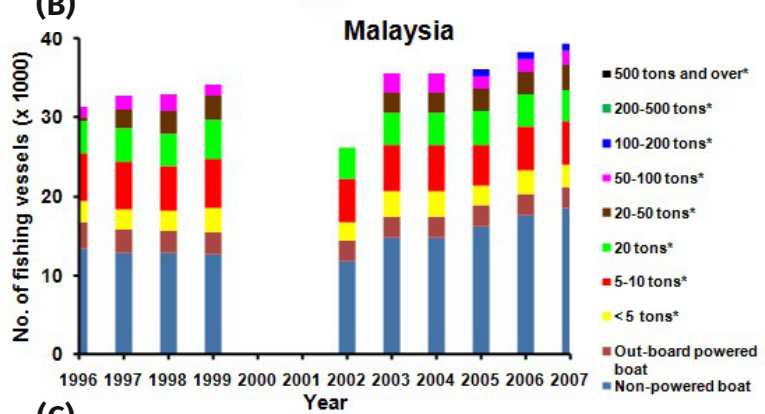
(c)

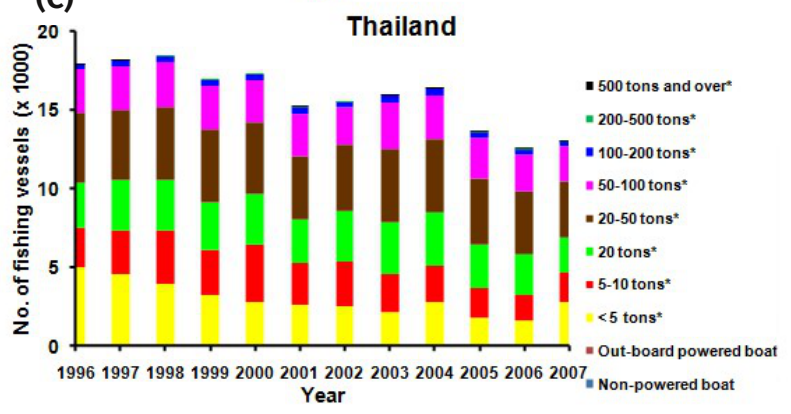

Figure 4. Trends in marine fishing vessel fleet sizes over time between 1996 to 2007. (A) Indonesia, (B) Malaysia, (C) Thailand; *inboard powered boats.
$52.2 \%$ respectively. In contrast, crustacean landings decreased by $26.0 \%$, over the same period (Figure 3C). Out of the 41 fishery groups assessed, stock of one group had collapsed, three groups were overfished, 35 fully exploited, whereas fisheries of two groups were developing (Table 2).

\subsubsection{Philippines}

Total demersal landings increased from 0.790 MMT in 1996 to 1.370 MMT in 2007 (73.4\% increase). Landings of demersal fishes, crustaceans and molluscs increased by $40.5 \%, 457.32 \%$ and $6.7 \%$, respectively, during the above period (Figure 3D). Out of the 45 fishery groups assessed, stocks of 11 groups were overfished, 33 groups fully exploited, whereas fishery of one group was developing (Table 2).

\subsubsection{Thailand}

Total demersal landings decreased from 1.944 MMT in 1996 to 1.463 MMT in 2007 (24.8\% reduction). Landings of demersal fishes, crustaceans and molluscs decreased by $21.4 \%, 51.8 \%$, and $26.9 \%$ respectively during the above period (Figure 3A). Out of the 37 fishery groups assessed, stocks of 16 groups were overfished, 20 fully exploited, whereas fishery of one group was developing (Table 2).

\subsection{Overall trends of fishing fleet size}

Available datasets for the number of marine fishing vessels from four countries for the period from 1996 to 2007 revealed a substantial increase in the size of the Indonesian (40.7\%; Figure 2F) and Malaysian (25.3\%; Figure 2G) fishing fleets. The size of the Myanmar fleet increased only marginally (11.6\%). On the other hand, there was substantial reduction in the number of Thai $(27.3 \%$; Figure 2J) fishing vessels. Trends for the remaining five countries (Brunei Darussalam, Cambodia, Philippines, 
(A)

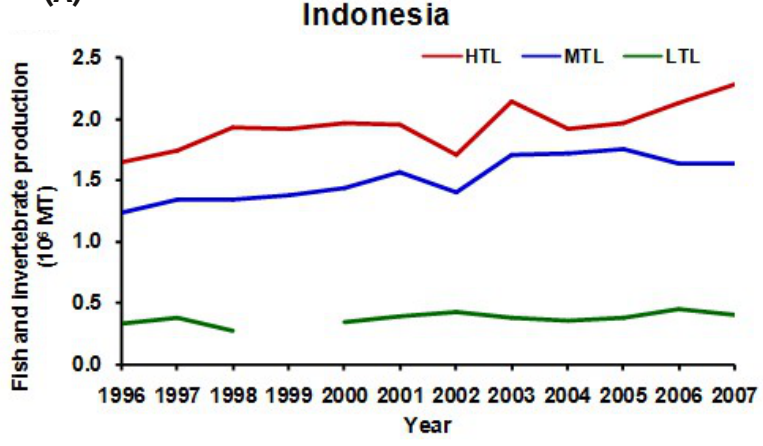

(c)

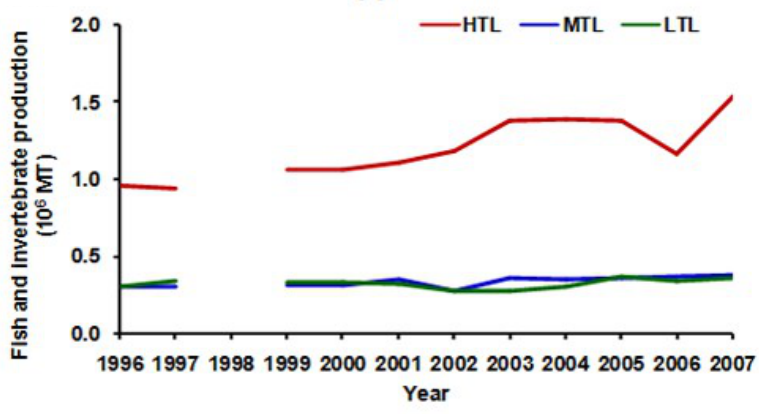

(B)

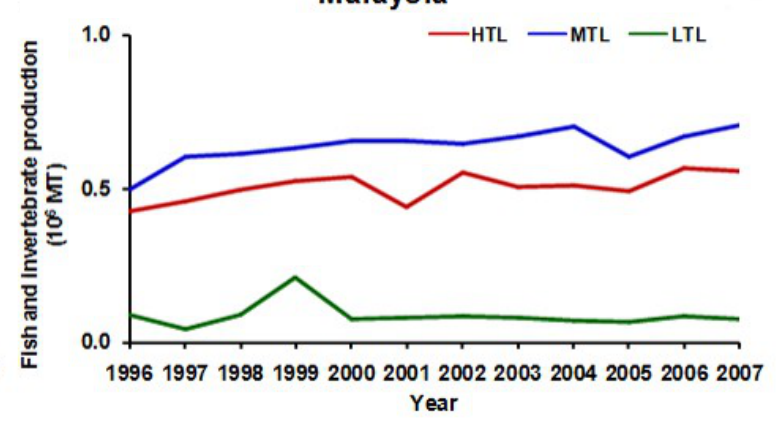

(D)

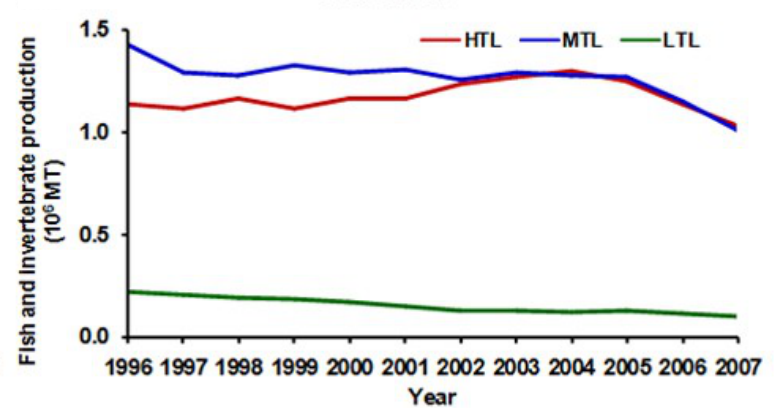

Figure 5. Comparative catch trends of various trophic groups for (A) Indonesia, (B) Malaysia, (C) Philippines and (D) Thailand, during 1996-2007. See text for abbreviations.

Singapore and Vietnam) were not assessed due to insufficient data (Figure 2B-E, 2I). However, fishing effort for Singapore was not considered as the fishery fleet for marine capture fisheries of this nation is very small (less than five vessels), and fishery yield is generated mostly by private fishermen (Figure $2 \mathrm{H}$ ).

Segregated datasets for size categories of marine fishing vessels revealed that traditional/artisanal nonpowered boats dominated the fishing fleets of Indonesia (Figure 4A) and Malaysia (Figure 4B). On the other hand, small-capacity inboard-powered vessels (up to 50 tons) dominated the Thai fishing fleet (Figure 4C).

\subsection{Catch trends at various trophic levels: A comparison}

In the case of Thailand and Malaysia, the mean MTL catches for the period from 1996-2007 were higher than HTL and LTL species (Figure 5A-B), whereas mean HTL catches in Indonesia and Philippines far exceeded MTL and LTL catches (Figure 5C-D).

\subsection{Fishery indices (country-wise trends)}

MTI of Malaysian marine demersal fisheries increased significantly $\left(\mathrm{R}^{2}=0.78\right)$ during 1996-2007 (Figure 6a). MTI of Thai, Philippine and Indonesian fisheries increased marginally $\left(\mathrm{R}^{2}=0.338,0.261,0.125\right.$, respectively; Figure $6 \mathrm{~B}-\mathrm{D})$ during the above period. FiB of Malaysian, Philippine, Indonesian marine demersal fisheries increased marginally $\left(\mathrm{R}^{2}=0.827,0.471,0.456\right.$, respectively) during 1996-2007 (Figure 6A, 6C-D). FiB of Thai fisheries decreased marginally $\left(R^{2}=0.075\right)$ during the above period (Figure 6B).

\subsection{Coral bleaching and HAB events}

A review of published literature pertaining to catastrophic marine events such as large-scale coral bleaching and extensive $\mathrm{HAB}$ formations during 1996-2007 revealed that these events were largely associated with the El Niño phenomenon that originated in the Eastern Pacific region (Table 3 ).

\section{DISCUSSION}

Analysis of recent trends (1996-2007) of marine fish and invertebrate production throughout Southeast Asia indicated $41 \%$ growth in the marine capture fisheries sector. Contemporary global marine capture fisheries trends indicated an overall drop of $10 \%$ in landings (FAO, 2011). A noteworthy boom was witnessed in the mariculture sector throughout Southeast Asia, which was concurrent with recent global trends (FAO, 2011). Further analysis of available data on total seafood production (including pelagic and demersal fisheries) in four countries, namely Indonesia, Malaysia, Philippines and Thailand (data combined) suggested a very slow growth rate (18.1\%) during 1996-2007. Contemporaneously, demersal (and benthopelagic) fish production increased by $17.8 \%$. However, there was a marginal decrease in MTI of Southeast Asian demersal fisheries (concurrent with global trends) largely due to a surge in the exploitation of HTL and MTL species. Analysis of the seafood production trends by country suggested that there were disparities in the growth rates of marine fisheries of individual countries and the same has been discussed here on the basis of a trophic web hypothesis.

It is well established that in a generalized marine ecosystem, anthropogenic removal (fishing) of a particular trophic level would have broad implications for the entire marine food web (Steneck 1998). For example, the removal of top predators and HTL species would cause:

(A1) lowering of predation pressure on the MTL species (Sala et al. 1998);

(A2) proliferation of MTL species would facilitate the creation of an "omnivore niche" resulting in significant loss of LTL species including planktivorous 
(A)

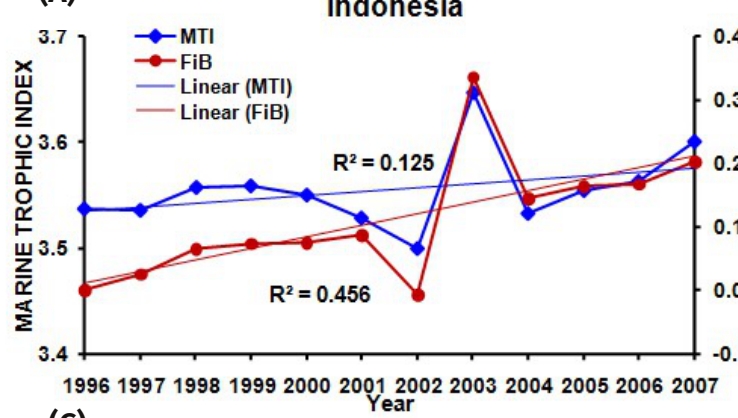

(c)

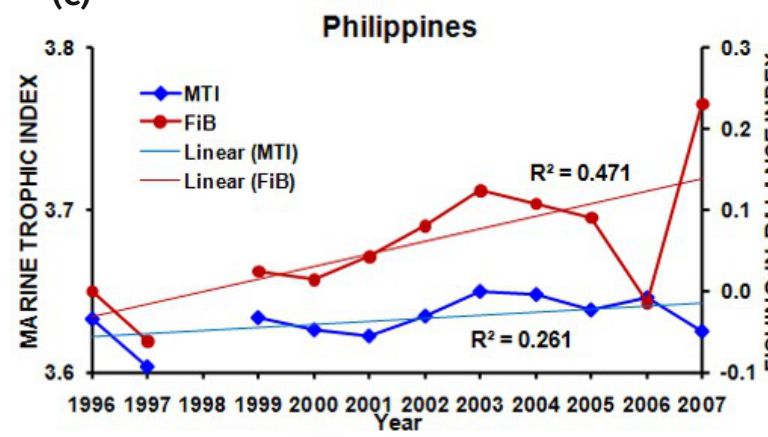

(B)

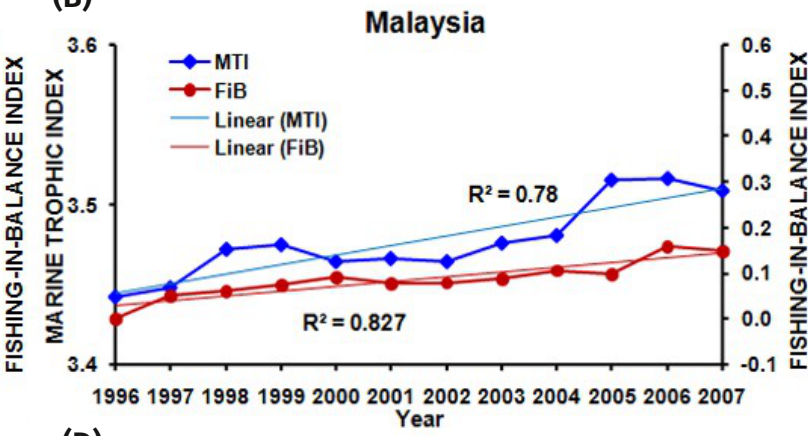

(D)

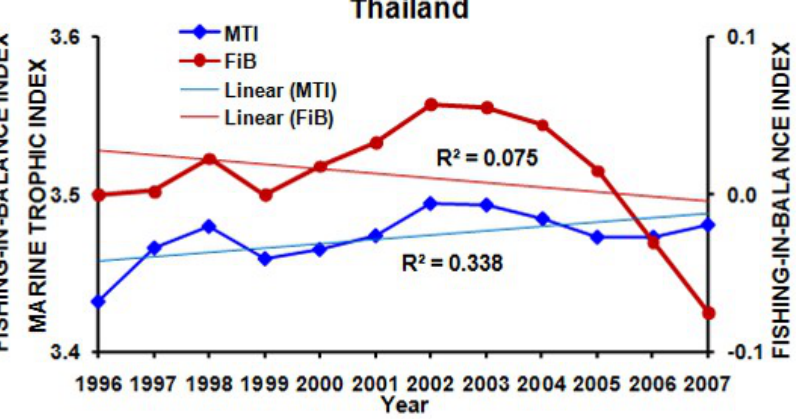

Figure 6. Trends of MTI (mid-trophic level) and FiB (fishing-in-balance) for marine demersal fisheries in four Southeast Asian countries. (A) Indonesia, (B) Malaysia, (C) Philippines, and (D) Thailand, during 1996-2007.

fishes and zooplankton;

(A3) reduction in LTL biomass would lower the grazing pressure resulting in significant increase in standing crop of phytoplankton;

(A4) sinking of unutilized phytoplankton biomass followed by microbial decomposition and re-mineralization would alter stoichiometric elemental C: N: P ratios (Ducklow et al. 2001);

(A5) organic matter accumulated at the sediment-water interface would support a detritus-based food web.

The removal of MTL species would cause:

(B1) decline in HTL species owing to absence of prey (Pauly et al. 1998);

(B2) proliferation of LTL species due to decreased predation pressure (Pauly et al. 1998);

(B3) suppression of plankton standing crop due to uncontrolled grazing.
The removal of LTL species would:

(C1) release predation pressure from phytoplankton causing extensive blooms;

(C2) cause "bottom-up trophic cascade" i.e., reduction of MTL, and consequently HTL species, resulting in a diminished marine fish community.

Alterations in trophic structure of marine communities would be greatly influenced by the geographical and bathymetric setting of that ecosystem. In an open ocean environment with a stratified water column, the regenerated nutrients are not transported to the subsurface waters owing to a strong pycnocline, indicating absence of benthicpelagic coupling. Moreover, in the absence of an external nutrient source, the subsurface waters become oligotrophic. In such an event, ephemeral small sized cells dominate the phytoplankton community, and the phytoplankton biomass so generated is inadequate to sustain primary pro-

Table 3. Catastrophic events in the coastal waters off four Southeast Asian countries during 1996-2007; abbreviations used: CB - Coral bleaching; HAB Harmful Algal Bloom formation.

\begin{tabular}{|c|c|c|c|c|}
\hline \multirow[t]{2}{*}{ Country } & \multirow[t]{2}{*}{ Intensity of El-Niño/La Niña effect } & \multicolumn{2}{|c|}{ Type of catastrophic event } & \multirow[t]{2}{*}{ Reference } \\
\hline & & Coral reef bleaching & Harmful algal bloom formation & \\
\hline Thailand & strong El-Niño (1998) & 1998 & & $\begin{array}{l}\text { Reaser et al. }(2000)^{C B} \\
\text { Yeemin et al. }(2009)^{C B}\end{array}$ \\
\hline Indonesia & $\begin{array}{l}\text { strong El-Niño (1998) } \\
\text { strong La Niña (1998) }\end{array}$ & 1998 & & Reaser et al. $(2000)^{\mathrm{CB}}$ \\
\hline Malaysia & $\begin{array}{l}\text { strong El-Niño (1998) } \\
\text { weak El-Niño (2006-2007) }\end{array}$ & 1998 & $\begin{array}{l}\text { 1996-1998, 2000-2002, 2005-2007; } \\
\text { major ones in 1996-1998 and } 2005\end{array}$ & $\begin{array}{l}\text { Reaser et al. }(2000)^{\mathrm{CB}} \\
\text { Teen et al. }(2012)^{\mathrm{HAB}} \\
\text { Azanza et al. }(2005)^{\mathrm{HAB}} \\
\text { Wang et al. }(2008)^{\mathrm{HAB}}\end{array}$ \\
\hline Philippines & $\begin{array}{l}\text { strong El-Niño (1998) } \\
\text { strong La Niña (1998) }\end{array}$ & 1998 & $\begin{array}{l}1996-2003,2005 ; \text { major ones in } \\
1996-1999 \text { and } 2002\end{array}$ & $\begin{array}{l}\text { Reaser et al. }(2000)^{\mathrm{CB}} \\
\text { Arceo et al. }(2001)^{\mathrm{CB}} \\
\text { Azanza et al. }(2005)^{\mathrm{HAB}} \\
\text { Wang et al. }(2008)^{\mathrm{HAB}}\end{array}$ \\
\hline
\end{tabular}


Table 4. Years of peak production of fishery groups (or species) exploited by four Southeast Asian countries (which were followed by decline in production) over the period 1996-2007.

\begin{tabular}{|c|c|c|c|c|}
\hline \multirow[t]{2}{*}{ Country } & \multirow{2}{*}{$\begin{array}{l}\text { Year of peak } \\
\text { production }\end{array}$} & \multicolumn{3}{|c|}{ Fisheries and respective trophic level groups } \\
\hline & & HTL & MTL & LTL \\
\hline \multirow[t]{9}{*}{ Thailand } & 1996 & eastern little tuna, black pomfret & $\begin{array}{l}\text { trash fish, mangrove crabs, } \\
\text { other prawns }\end{array}$ & sardines \\
\hline & 1997 & $\begin{array}{l}\text { other sp. (redfishes etc.), } \\
\text { Indian halibuts }\end{array}$ & & \\
\hline & 1998 & $\begin{array}{l}\text { swimming crabs, barramundi, } \\
\text { octopuses, hairtail scad }\end{array}$ & penaeid prawns & \\
\hline & 1999 & & slipper lobster & scallops \\
\hline & 2000 & & catfish eels & \\
\hline & 2001 & & mullets & \\
\hline & 2002 & $\begin{array}{l}\text { lizardfishes, cuttlefishes, squids, } \\
\text { narrow-barred king mackerel, } \\
\text { groupers, barracudas, round scad, } \\
\text { wolf herring, threadfin breams }\end{array}$ & tonguesoles & \\
\hline & 2003 & sharks, rays, queenfishes, selar scad & $\begin{array}{l}\text { seabass and miscellaneous } \\
\text { fishes }\end{array}$ & \\
\hline & 2004 & red snappers & marine catfishes & blood cockles \\
\hline \multirow[t]{6}{*}{ Indonesia } & 1998 & other sp. (jacks etc.) & & \\
\hline & 1999 & barracudas & & \\
\hline & 2000 & & & cupped oysters \\
\hline & 2003 & wolf herring, eastern little tuna & & \\
\hline & 2004 & & $\begin{array}{l}\text { miscellaneous marine } \\
\text { crustaceans }\end{array}$ & \\
\hline & 2005 & & $\begin{array}{l}\text { seabass and miscellaneous } \\
\text { fishes, spiny lobsters }\end{array}$ & \\
\hline \multirow[t]{9}{*}{ Malaysia } & 1996 & & other prawns & \\
\hline & 1997 & & fusiliers & \\
\hline & 1998 & black pomfret, other snappers & & \\
\hline & 1999 & $\begin{array}{l}\text { eels, groupers, red snappers, } \\
\text { other sp. (jacks etc.), Indian halibut, } \\
\text { barracudas, swimming crabs }\end{array}$ & & \\
\hline & 2000 & & mullets & \\
\hline & 2002 & longtail tuna & spiny lobsters & \\
\hline & 2003 & & tiger prawn & \\
\hline & 2004 & & penaeid prawns & \\
\hline & 2005 & & ponyfishes & \\
\hline \multirow[t]{6}{*}{ Phillippines } & 1996 & $\begin{array}{l}\text { sharks, rays, barramundi, black } \\
\text { pomfret, drums and croakers, } \\
\text { emperor breams, bigeye snappers, } \\
\text { lizardfishes, octopuses }\end{array}$ & $\begin{array}{l}\text { mangrove crabs, spiny lobster, } \\
\text { slipper lobster }\end{array}$ & $\begin{array}{l}\text { cupped oysters, blood } \\
\text { cockles, clams and cone } \\
\text { shells, shads }\end{array}$ \\
\hline & 1997 & cuttlefishes & & \\
\hline & 1999 & & & round herring \\
\hline & 2001 & & other prawns & \\
\hline & 2002 & & grunters and sweetlips & \\
\hline & 2003 & wolf herring, barracudas & & \\
\hline
\end{tabular}

ductivity (Kiørboe 2008). Simultaneously, anoxic or hypoxic conditions in the bottom waters would induce anaerobic catabolism of the organic matter accumulated at the sediment-water interface. Additionally, low dissolved oxygen concentrations would interfere with the physiological processes of the benthic faunal communities either causing mortality or forcing emigration. On the other hand, in coastal waters with well-mixed water column prone to cyclonic wind circulation, the regenerated nutrients in the bottom waters would be transported to the subsurface waters, indicating prevalence of benthic-pelagic coupling. Moreover, nutrient loading from terrestrial sources would render these waters eutrophic, and the phytoplankton com- munity may become dominated by long-lived large sized cells (Kiørboe 2008). Simultaneously, well-oxygenated bottom waters would support myriad communities of benthic fishes and invertebrates.

In view of the above hypothesis, it is noteworthy that the major bulk of the Southeast Asian demersal marine fisheries are restricted to the shallow coastal waters, whereas both coastal and deeper water fisheries exploit pelagic species. However, demersal deep-sea fisheries of the individual countries are evolving rapidly (Saharuddin 1995; Flores 2004; Morgan and Staples 2006).

A significant reduction in LTL species production by Thailand along with marginal reduction in MTL and HTL 
species production partially suggested the occurrence of a partial "top down" trophic cascade effect (involving A1, A2, A3). This effect was attributed to multiple factors, but primarily due to the long-term negative effects of large scale bottom trawling in the Gulf of Thailand and Andaman Sea since the 1960's. Secondly, the decline in catches of mangrove crabs, penaeid and non-penaeid prawns as well as myriad trash fish species after 1996-1998 was attributed to large scale mariculture and urbanization that destroyed some of the vital mangrove habitats. Thirdly, the massive coral bleaching event of 1998 probably caused a gradual decline in HTL reef fishes (Table 4). Further, anthropogenic nutrient enrichment of the coastal waters of Gulf of Thailand resulted in frequent plankton blooms (Wattayakorn 2006).

In the case of Indonesia and Malaysia, the ecological implications of removal of considerable quantities of fish biomass across the trophic spectrum could not be explained explicitly. Increase in seafood production at all trophic levels roughly corresponded with increase in the size of the fishing fleets (particularly artisanal nonpowered boats and inboard powered mechanized vessels), and the geographical expansion of fishing grounds (Pauly 2013). Marine basins across Southeast Asia, with the exception of the Gulf of Thailand, were not exploited intensively to depletion levels prior to 1996, and many of their coral reefs, although at very high risk from anthropogenic disturbances, were in marginally better conditions (Burke et al. 2002). This probably explained why, despite the widespread coral bleaching event of 1998, the coral reefs could withstand fishing pressure, thereby returning marginally higher yields in terms of seafood production. Moreover, the increased use of artisanal fishing vessels might have minimized destruction of bottom reef structures. However, caution must be exercised while interpreting these trends as 71 and $85 \%$ of the demersal fisheries (including reef-associated species) of Indonesia and Malaysia, respectively were fully exploited and another $10 \%$ were overfished. Furthermore, production of a few HTL species declined strongly after 1998-1999 (Table 4) mostly due to the 1998 coral bleaching event. Another factor affecting the coastal marine habitats of the South China Sea was nutrient enrichment and sedimentation of coastal waters from domestic sewage and highly dense aquaculture farms (Wang et al. 2008). Circulation of these enriched waters was affected due to seasonal changes of winds and current patterns thus facilitating long distance transportation of HAB-causing species (Azanza et al. 2005). Therefore, it is conjectured that the marine basins exploited by these countries could be heading towards a "top down" trophic cascade effect (involving A1-5; see above).

In the Philippines, production of a few HTL species declined strongly after 1996 (Table 4) due to targeted exploitation and destructive fishing practices (Gomez et al. 1994). In addition, production of mangrove-associated crustaceans and molluscs declined after 1996 (Table 4) probably due to habitat loss. However, decline in their catches did not have any significant effect on the total seafood production trends during 1996-2007 largely due to maximized fishing effort coupled with geographical expansion of fishing areas. It is conjectured that continuous increase in fishing effort and use of destructive fishing techniques coupled with changes in land use pattern would potentially endanger most coastal ecosystems (Burke et al. 2002) and lead to a "top down" trophic cascade effect in the near future. A few manifestations of this ecological effect such as recurrent phytoplankton blooms (A3) were prevalent dur- ing this period, which frequently resulted in massive fish kills (Relox and Bajarias 2003; Azanza et al. 2005).

It is apparent from above that the marine living resources of Southeast Asia are afflicted by demand-driven overexploitation (Mamauag 2004; Ochavillo et al. 2004), and the consequences of ecosystem alteration (Burke et al. 2002). Intensive exploitation of coastal and offshore living resources throughout Southeast Asia has resulted in the overexploitation of most HTL and MTL species. Furthermore, unrestrained alterations of land-use pattern as well as coastal habitats to serve the increasing demands of the ever-growing demographic pressure have also caused immense damage to these ecosystems (Burke et al. 2002). In the light of this scenario, excessive anthropogenic sedimentation and eutrophication may cause hypoxic (or anoxic) conditions, thereby accelerating anaerobic decomposition and compelling HAB-forming species to switch to mixotrophic (combined phototrophy and heterotrophy) mode of nutrition (Burkholder et al. 2008). Moreover, in tropical waters, elevated temperature regimes intensify decomposition, but also stratify the water column as well as stimulate excessive planktonic growth (Hallegraeff 2010). The most apparent manifestations of these disturbances during the last few decades were the recurring HABs (Wang et al. 2008; Lim et al. 2012) those are responsible for large scale fish mortality (Relox and Bajarias 2003; Azanza et al. 2005), as well as potential hazards to the coastal human population (Backer and McGillicuddy 2006).

A rapidly changing global climate has intensified the El Niño phenomenon resulting in higher SST, altered monsoonal sequences, and increased rates of $\mathrm{CO}_{2}$ dissolution those interfere with the biological processes of the symbiotic zooxanthellae, whose mortality has resulted in mass coral bleaching events (Reaser et al. 2000). Climate change also accelerates speciation and extinction of native fauna through changes in thermal (Sanciango et al. 2013) and $\mathrm{pH}$ regimes of the ambient ecosystems and creates opportunities for the establishment of resilient opportunistic (Mohamed et al. 2013) and invasive species (Occhipinti-Ambrogi 2007) that would further modify the trophic dynamics of the coastal habitats.

\section{ACKNOWLEDGEMENTS}

The authors are grateful to the Ballast Water Management Programme, India executed by the National Institute of Oceanography, Dona Paula, Goa for the Directorate General of Shipping, Ministry of Shipping, Government of India. The contents of this manuscript were first presented at the ASEAN-India international conference on the extent of transfer of alien invasive organisms in South/Southeast Asia region by shipping, held in Chiang Mai, Thailand from 26 to 28 November 2013. We thank the ASEAN Committee for Science and Technology (COST) and Ministry of External Affairs, India for their generous support.

\section{REFERENCES}

Armada NB. 2004. State of the demersal fisheries. In: Silvestre G, Green SJ, White AT, Armada N, Luna C, Cruz-Trinidad A, Carreon III MF, editors. In turbulent seas: the status of Philippine marine fisheries. Manila: Department of Agriculture, Bureau of Fisheries and Aquatic Resources. p. 42-46.

Azanza RV, Fukuyo Y, Yap LG, Takayama H. 2005. Prorocentrum minimum blooms and its possible link to 
a massive fish kill in Bolinao, Pangasinan, Northern Philippines. Harmful Algae 4:519-524.

Backer LC, McGillicuddy DJ. 2006. Harmful algal blooms: at the interface between coastal oceanography and human health. Oceanography 19:94-106.

Barut NC, Santos MD, Garces LR. 2004. Overview of Philippine marine fisheries. In: Silvestre G, Green SJ, White AT, Armada N, Luna C, Cruz-Trinidad A, Carreon III MF, editors. In turbulent seas: the status of Philippine marine fisheries. Manila: Department of Agriculture, Bureau of Fisheries and Aquatic Resources. p. 22-31.

Burke L, Selig E, Spalding M. 2002. Reefs at risk in Southeast Asia. Washington DC: World Resources Institute.

Burkholder JM, Glibert PM, Skelton HM. 2008. Mixotrophy, a major mode of nutrition for harmful algal species in eutrophic waters. Harmful Algae 8:77-93.

Ducklow HW, Steinberg DK, Buesseler KO. 2001. Upper ocean carbon export and the biological pump Oceanography 14(4):50-58.

FAO. 2011. Review of the state of world marine fishery resources. FAO Fisheries and Aquaculture Technical Paper 569. p. 1-334.

Flores JO. 2004. Fisheries in deep-water areas of the Philippines. In: Silvestre G, Green SJ, White AT, Armada N, Luna C, Cruz-Trinidad A, Carreon III MF, editors. In turbulent seas: the status of Philippine marine fisheries. Manila: Department of Agriculture, Bureau of Fisheries and Aquatic Resources. p. 72-78.

Froese R, Kesner-Reyes K. 2002. Impact of fishing on the abundance of marine species. ICES CM 2002/L 12:1-15.

Froese R, Pauly D, editors. 2013. FishBase. [accessed 2013 Dec 28]. http://www.fishbase.org.

Gomez ED, Aliño PM, Yap HT, Licuanan WY. 1994. A review of the status of Philippine reefs. Marine Pollution Bulletin 29(1-3):62-68.

Hallegraeff GM. 2010. Ocean climate change, phytoplankton community responses and harmful algal blooms: a formidable predictive challenge. Journal of Phycology 46(2):220-235.

Hutomo M, Moosa MK. 2005. Indonesian marine and coastal biodiversity: present status. Indian Journal of Marine Sciences 34(1):88-97.

Kathiresan K, Rajendran N. 2005. Mangrove ecosystems of the Indian Ocean region. Indian Journal of Marine Sciences 34(1):104-113.

Keesing J, Irvine T. 2005. Coastal biodiversity in the Indian Ocean: the known, the unknown and the unknowable. Indian Journal of Marine Sciences 34(1):11-26.

Kiørboe T, editor. 2008. A mechanistic approach to plankton ecology. Princeton: Princeton University Press.

Lim PT, Gires U, Leow CP. 2012. Harmful algal blooms in Malaysian waters. Sains Malaysiana 41(12):1509-1515.

Mamauag S. 2004. The live reef food fish trade in the Philippines. In: Silvestre G, Green SJ, White AT, Armada N, Luna C, Cruz-Trinidad A, Carreon III MF, editors. In turbulent seas: the status of Philippine marine fisheries. Manila: Department of Agriculture, Bureau of Fisheries and Aquatic Resources. p. 53-59.

Mazlan AG, Zaidi CC, Wan-Lotfi WM, Othman BHR. 2005. On the current status of coastal marine biodiversity in Malaysia. Indian Journal of Marine Sciences 34(1):76-87.
Mohamed KS, Sathianandan TV, Kripa V, Zacharia PU. 2013. Puffer fish menace in Kerala: a case of decline in predatory control in the southeastern Arabian Sea. Current Science 104(4):426-429.

Morgan GR, Staples DJ. 2006. The history of industrial marine fisheries in Southeast Asia. Bangkok: Food and Agricultural Organization of the United $\mathrm{Na}-$ tions, Regional Office for Asia and the Pacific.

Occhipinti-Ambrogi A. 2007. Global change and marine communities: alien species and climate change. Marine Pollution Bulletin 55:342-352.

Ochavillo D, Hodgson S, Shuman C, Ruz R. 2004. Status of the Philippine marine aquarium fish. In: Silvestre G, Green SJ, White AT, Armada N, Luna C, Cruz-Trinidad A, Carreon III MF, editors. In turbulent seas: the status of Philippine marine fisheries. Manila: Department of Agriculture, Bureau of Fisheries and Aquatic Resources. p. 60-64.

Pauly D. 2013. Sea around us project. [accessed 2013 Jul 15]. http://www.seaaround.org.

Pauly D, Christensen V, Dalsgaard J, Froese R, Torres FC Jr. 1998. Fishing down marine food webs. Science 279:860-863.

Pauly D, Christensen V, Walters C. 2000. Ecopath, Ecosim, and Ecospace as tools for evaluating ecosystem impact of fisheries. ICES Journal of Marine Science 57:697-706.

Reaser JK, Pomerance R, Thomas PO. 2000. Coral bleaching and global climate change. Conservation Biology 14(5):1500-1511.

Relox JR, Bajarias FFA. 2003. Harmful Algal Blooms (HABs) in the Philippines. In: Furuya K, Fukuyo Y, editors. Extended abstracts of workshop on red tide monitoring in Asian coastal waters. Tokyo: University of Tokyo. p. 65-68.

Saharuddin AH. 1995. Development and management of Malaysian marine fisheries - technical conservation measures. Marine Policy 19(2):115-126.

Sala E, Boudouresque CF, Harmelin-Vivien M. 1998. Fishing, trophic cascades, and the structure of algal assemblages: evaluation of an old but untested paradigm. Oikos 83:425-439.

Sanciangco JC, Carpenter KE, Etnoyer PJ, Moretzsohn F. 2013. Habitat availability and heterogeneity and the Indo-Pacific warm pool as predictors of marine species richness in the Tropical Indo-Pacific. PLoS ONE 8:e56245.

SEAFDEC. 2013. Fishery statistics in the South China Sea Area 1976-2007. [place unknown]: SEAFDEC; [accessed 2013 Jun 12]. http://fishstat.seafdec.org/statistical_bulletin/index.php.

Son DM, Thuoc P. 2003. Management of coastal fisheries in Vietnam. In: Silvestre G, Garces L, Stobutzki I, Ahmed M, Valmonte-Santos RA, Luna C, Lachica-Aliño L, Munro P, Christensen V, Pauly D, editors. Assessment, management and future directions for coastal fisheries in Asian countries. WorldFish Center Conference Proceedings 67:957-986.

Steneck RS. 1998. Human influences on coastal ecosystems: does overfishing create trophic cascades?. Trends in Ecology and Evolution 13(11):429-430.

Vivekanandan E, Srinath M, Kuriakose S. 2005. Fishing the marine food web along the Indian coast. Fisheries Research 72:241-252.

Wang SF, Tang DL, He FL, Fukuyo Y, Azanza RV. 2008. Occurrences of harmful algal blooms (HABs) associated with ocean environments in the South China Sea. 
Hydrobiologia 596:79-93.

Wattayakorn G. 2006. Environmental issues in the Gulf of Thailand. In: Wolanski E, editor. The Environment in Asia Pacific Harbours. The Netherlands: Springer. p. 249-259.

Appendix 1. List of pelagic fish species included for hypothesizing ecological responses.

\begin{tabular}{ll}
\hline Trophic group & Species/groups \\
\hline LTL & clupeoids, shads, sardines, round herring \\
MTL & anchovies, fusiliers, indian mackerels \\
HTL & barracudas, hairtail scad, half beaks and needle fishes, Indo-Pacific mackerel, narrow-barred king \\
& mackerel, skip jack tuna, long tail tuna, yellow fin tuna, eastern little tuna, frigate and bullet tuna, \\
& swordfishes, sailfishes and marlins \\
\hline
\end{tabular}


